\title{
Orientalism and the Study of the Pre-modern Middle East
}

\begin{abstract}
By Walter D. Ward*
Edward Said's Orientalism (1978) argued that the image of the Middle East (Orientalism) that was created by "western" (mainly French) writers and artists in the 19th century justified European imperialism in the region. Similar justifications can be detected in modern authors, such as Huntington's "Clash of Civilizations" which supports modern imperialist activity in the Middle East. This paper investigates how Orientalism and its modern derivations can and cannot be applied to the study of the pre-modern Middle East, using two concrete examples: urbanism in the Middle East during the Greco-Roman period (c. 323 BCE - c. 300 CE) and the early Islamic conquests of the Middle East in the seventh century CE. I will argue that using presentist and 19 th century frames of reference concerning "east" and "west" are misleading, simplistic, and modes of thinking that actually obscure the complexities of everyday interaction in the pre-modern Middle East.
\end{abstract}

Keywords: Imperialism, Middle East, Orientalism, Urbanism.

\section{Introduction}

"This is Sparta!" the handsome, white, muscular man yells as he kicks a black man dressed in "eastern" robes into a pit. In this scene from the Warner Brothers' movie 300 and throughout the entire picture, the Persians and their subjects are depicted as exotic, sometimes monstrous, creatures who are slaves to effeminate Persian god-kings. In another sweeping fantasy epic, New Line Cinema's The Lord of the Rings, evil men called Haradim ride on gigantic Oliphants, dressed in Arab-like costumes with turbans. The Haradim exist in the movie purely for the white, Anglo-Saxon-like medieval cavalry to kill. Both of these movies suggest that the white warriors are fighting for freedom vs. an exotic and evil Other. My first thought after watching the 300 film was, "Edward Said must be rolling in his grave right now."

Edward Said's opus Orientalism (1978) elucidated, for the first time, the implicit assumptions that went into crafting the image of Middle Easterners as an exotic other - a foil for white Europeans to oppose (Said 1978). He argued that the image of the Middle East (which he called Orientalism) was created by "western" (mainly French) writers and artists in the 19th century to justify, consciously or unconsciously, European imperialism in the region. Orientalist descriptions of the Middle East remain alive today as demonstrated in the preceding paragraph, and they shape the way that the average person (especially American) understands the Middle East. Similar, but even more violent, depictions can be detected in works by modern authors, such as Huntington's "Clash of

* Associate Professor, Department of History, University of Alabama at Birmingham, USA. 
Civilizations" which has been used to support modern American imperialist activity in the Middle East (Huntington 1993).

My goal for this paper is to investigate how an Orientalist framework has been applied to the study of the pre-modern Middle East, using two concrete examples: urbanism in the Middle East during the Greco-Roman period (c. 323 BCE - c. $300 \mathrm{CE}$ ) and the early Islamic conquests of the Middle East (seventh century CE). I will argue that presentist (or perhaps 19th century) frames of reference concerning "east" and "west" still occur among scholars despite the fact that they are misleading, simplistic modes of thinking that obscure the complexities of everyday interaction in the pre-modern Middle East.

\section{Orientalism}

Prior to the Second World War, the study of Middle Eastern society and culture was primarily in the hands of "Western" scholars, so-called "Orientalists," who predominately used philological methods. They examined Middle Eastern society through the lens of the colonial ventures of the eighteenth and early nineteenth centuries. Said famously argued that these Orientalists projected exoticism and weakness onto the "East" (Muslim Arabs especially) in order to justify colonial endeavors in the Middle East at the height of imperialism during the long nineteenth century.

Said described Orientalism as "a way of coming to terms with the Orient" (1) "a style of thought based upon an ontological and epistemological distinction made between 'the Orient' and 'the Occident'" (2) "a Western style for dominating, restructuring, and having authority over the Orient" (3) and, "a system of representations framed by a whole set of forces that brought the Orient into Western learning, Western consciousness, and later, Western empire" (203). Said believed that the discourse about the Orient - the creation of stereotypes was simply a representation of the "East" that occurred in the imagination of Western scholars - and that this representation did not depend on any actual qualities that existed in the Orient. In a sense, it "displaced" the "real" Orient (21-22).

Said traced the beginnings of the Orientalist approach towards the "East" back to classical Greek works, such as the Persae. Only one reading of Herodotus's History of the Persian Wars and then a viewing of the film 300 is necessary to see that the rhetoric and depiction of easterners by the ancient Greeks was formative in the development of modern ideas about the Middle East. Nevertheless, it seems hard to reconcile classical Greek (and later Roman and early Christian) views of "the East" with nineteenth century justifications of imperialism because of the very different historical contexts. At the very least, it is intellectually suspect to draw a connection from the Greek ideas of the Other directly to the modern period without taking stock of the immense changes that occurred over two millennia of discourse, especially as Christianity, Islam, and then the Enlightenment became prime drivers of identity and thought (Hentsch 1992: esp. 18-20; Lockman 2004: 1-19). 
"West" vs. "East"

As America and other NATO countries have become engaged in protracted wars in the Middle East since 9/11, Samuel Huntington's famous Foreign Affairs article, "The Clash of Civilizations?," has exerted an immense influence on geo-political discussions, especially at the policy level. Huntington argued that future conflicts would be between different "civilizations," which he defined based on culture but especially religion. More specifically, Huntington's thesis was not that all civilizations were bound to fight against each other; rather, conflict would be between "Islamic" civilization and the rest, with Muslim aggression especially directed towards "Western" civilization. In his words, "Islam has bloody borders." (Huntington 1993, 35.)

This thesis has not been well-received by academics, but has remained influential in non-academic circles, perhaps because Huntington coined a catchy name for ideas that already had a wide circulation, a "political myth." (See Bottici and Challand 2010: esp. 1-2, 9-25, 95-110). It should also be pointed out that the term "Clash of Civilizations" originated in an essay by Bernard Lewis entitled," The Roots of Muslim Rage," in which Lewis blamed the "ancient rivalry against our Judeo-Christian heritage, our secular present, and the worldwide expansion of both" as a reasons for "Muslim rage" against the "West" (Lewis 1990) ${ }^{1}$. Huntington's model of the "Clash of Civilizations" has been adopted by various armchair generals and foreign policy "experts." New York Post and Fox News contributor, Ralph Peters, for example, has clearly internalized Huntington's thesis, while also criticizing it for ignoring "the gory fault lines within civilizations as well." (Peters 2010: 68). Others find it to be a useful tool to express their hatred and disdain for the Muslim world without being forced to use what most would consider racist language. They posit a world view in which America and its values are considered normative, while the values of Others are deemed primitive - at best, or barbaric - at worst (Gregory 2004: 20-29, 47-61). ${ }^{2}$

\section{Complicating "East" and "West"}

As mentioned above, recent academics have largely resisted a bipolar understanding of the world and point out the complexity of image creation and interaction that are blurred by Orientalist or "Clash" theories. For example, in the Myth of Continents, Lewis and Wigen describe how the twisted thought processes that led to the distinction of "East" and "West," were invented, using imagined code-words whose geographical boundaries constantly shifted as the idea of the "West" was refined. Furthermore, they demonstrate that the

\footnotetext{
${ }^{1}$ See Bulliet's criticism of both Huntington and Lewis (2004: 4-93) as well as Henderson and Tucker 2001, Fox 2002, Chiozza 2002, Bilgrami 2003, Neumayer and Plümper 2009.

${ }^{2}$ For example, Keegan 2001 denied that "peoples of the desert and the empty spaces exist on the same level of civilization as those who farm and manufacture" (i.e. the West). Gregory was left almost speechless, commenting, "I am not making this up" (2004: 59).
} 
characteristics which are thought to define "East" and "West" do not withstand intellectual scrutiny (Lewis and Wigen 1997: 47-103).

Furthermore, Richard Bulliet argued that the "West" could not exist in the same form as it does now without the complex relationship with Islamic history and intellectual borrowings from Islamic scholars during the medieval period (Bulliet 2004: esp. 1-45). ${ }^{3}$ In some ways this echoes Henri Pirenne's famous statement that Charlemagne could not have existed without Mohammad (Pirenne 2001: 234). Bulliet (2004: 30-33), however, believes that the importance of Islam on the formation of Europe was purposely erased to ensure that Islam was seen as an evil "Other" that did not contribute to Western society. A similar line of thinking can be seen in the study of troubador culture, which was fundamentally shaped by unacknowledged Muslim influences in Spain and southern France. Even many modern scholars have refused to recognize the importance of these Muslim influences on the creation of what is typically considered exemplars of "western" literature (Menocal 1987). ${ }^{4}$

\section{Urbanism in the Middle East in the Greco-Roman Period}

Having briefly surveyed the ways in which modern understandings of the Middle East have been shaped, I want to investigate how those understandings have influenced modern interpretations of the pre-modern world beginning with urbanism in the Middle East during the Greco-Roman period (c. 323 BCE - c. $300 \mathrm{CE})$.

In the late fourth century B.C.E., the Macedonian Kingdom under the leadership of Alexander the Great defeated the Persian Empire. Though Alexander's empire did not survive his death intact, the Macedonian successor kingdoms continued to rule over modern day Egypt, the Middle East, Persia, and Afghanistan. These rulers imported Greek and Macedonian colonists who either founded new cities (often named after their Macedonian rulers or cities from the Greek mainland), or completely transformed existing settlements. These successor states fought amongst themselves until the Roman state encroached into the eastern Mediterranean. The Romans first conquered the province they called Syria in 64/3 BCE, and slowly added the rest of the Near East west of Mesopotamia by $106 \mathrm{CE}$. In doing so, the Romans united the Mediterranean and the Near East for the first time in world history.

For many scholars, the period from the death of Alexander in $323 \mathrm{BCE}$ to about $300 \mathrm{CE}$ was the height of urbanism in the Near East. The settlements, founded by Macedonians and Greeks and developed under the Romans, were thought to be superior to earlier and later forms of urbanism. The title of Kennedy's famous article "From Polis to Madina" sums up this view - the "rational" city, the polis, with its Greek-style monumental structures disappeared and was replaced by an urban suq or bazaar with private buildings encroaching

\footnotetext{
${ }^{3}$ The intellectual borrowings and economic cooperation is an important topic in Fletcher 2004: esp. 100-130 and Lochman 2004: 31-33.

${ }^{4}$ See Lyons 2009 and Freely 2011 on the influence of Islamic science in the west.
} 
onto the formerly public streets - a Madina or "Islamic" city (Kennedy 1985). Though Kennedy argued against making value judgments about the past and stressed the continuity of urban life into the Islamic period, many scholars (and even Kennedy himself) have described this transformation as the "decline" and "decay" of the ancient city (Kennedy 1985:17-18).

Scholarship on these urban spaces has focused on the Greco-Roman character of the buildings and the written material created in them opposed to indigenous influences. Research at the present is influenced deeply by Fergus Millars' "The Roman Near East" in which Millar argues that all of the cities in the Near East were organized on a Greek model imported into Syria by the Greeks and later the Romans, and that Greek was the primary language of cultural expression (Millar 1993). In his view, Greco-Roman culture was dominant, with evidence of indigenous cultures relegated to the peripheral zones of settlement, such as the regions controlled by the Nabataean Kingdom or the oasis city of Palmyra. Millar's work concentrated on written sources, primarily inscriptions, which in the first through fourth centuries CE were written almost entirely in the Greek language (Palmyra and Nabataea excluded). This suggested to him that "Greek language, Greek social structures and Greek frameworks for the construction and worship of deities penetrated to the most remote of rural contexts" and therefore dominated the cultural life of the urban and rural elements of the Roman Near East (523).

Fergus Millar's conclusions have of course been influential but have been refined through later scholarship. Most others, such as Sartre and Butcher as mentioned below, have worked within the framework that Millar constructed, but Warwick Ball drew a diametrically opposite conclusion and argued that Greek culture was a thin "veneer" hiding a dominate Semitic, Near Eastern society (Ball 2000). Ball's primary evidence for this assertion was the archaeological remains of the cities, countryside, and individual monuments. One of Ball's chief arguments is that Greeks did not physically found new cities in the Near East. Instead, he argues that they used the claims of civic foundation as a way to appropriate previously existing communities for themselves. He suggests that since most of these "Greek" communities reverted to using the Semitic name for their cities after the Islamic conquest proves that these communities were predominately Semitic and not Greek.

Using surviving archaeological monuments, Ball concludes that the function of many structures was largely non-Greek even though they were designed with Greek elements. For example, he suggests that the colonnaded streets found throughout the Near East, at Apamea or Palmyra, for example, were intended as processional ways or as Near Eastern markets (a suq or bazaar). Therefore, even though the colonnaded streets appear to be Greco-Roman since they were often constructed with Corinthian-style columns, they were in fact used for typically indigenous purposes.

Ball also argues that the temples in the Near East were used for indigenous rituals even though they appear "western" in style. Some features that Ball concludes were Near Eastern, rather than Greco-Roman, include high places for sacrifice, as seen at the Temple of Jupiter at Baalbeck and Temple of Bel in 
Palmyra, circumabulatories inside temples (most often in the Nabataean realm), and large temenos squares with decorated propylae (entrances). He concludes, "[t]here are many resemblances [to Roman architecture], admittedly, and it would be folly to overlook them. But the resemblances are purely superficial. In terms of function, liturgy, antecedents and overall concept, these massive temple enclosures with their elaborate entrances have no counterpart in Roman architecture of the West" (329).

Two additional works, Butcher's Roman Syria and the Near East and Sartre's The Middle East under Rome argue for a more-middle ground between Millar's and Ball's polar extremes (Butcher 2003, Sartre 2005). Both Butcher and Sartre emphasize more complex relationships between identity, culture, and artifacts than the more polarized views of Millar and Ball. Butcher argues that Greek education and culture allowed an individual access to imperial and cultural power, and that individuals who chose to adopt of Hellenic culture obtained significant advantages, such as access to the power of the emperor, local autonomy, positions in the imperial bureaucracy, and, above all, entrance into a unified elite that spanned the entire empire. Sartre's The Middle East Under Rome makes a strong case that Greek or Indigenous are artificial terms and do not reflect life in Rome's Near Eastern provinces. Instead, he argues that these two cultures interacted to form a third culture which was a hybrid of the other two. He believes that the inhabitants were not adverse to living in many different cultural worlds but over time, Greek became the lingua franca to express those identities.

Most recently, Nathanel Andrade's Syrian Identity in the Greco-Roman World examines the development of Syrian expressions of Greekness (Andrade 2013). He argues that Syrians, writing in Greek and engaging in debates about the nature of Greek culture, influenced the development of Greek identity in ways that have previously gone unnoticed. He sees Greek and Syrian cultural expressions as overlapping sets utilizing polyvalent symbols (symbols with multiple meaning) which interacted in complex ways. In short, to define the Near East as either Greek (and Roman) or indigenous or a mixture simplifies the complex intertwining of people's identities. Andrade's evidence is primarily literary, for example, he argues on the basis of Lucian's On the Syrian Goddess, that Syrians both consumed and created Greek culture for their own purposes. Therefore we should see Syrians as co-opting Greco-Roman culture to advance themselves within the Greco-Roman system. Andrade, however, also examines Antioch, Apamea, and Jerash as examples of Near Eastern cities to argue that Greek and Syrian were categories that overlapped each other, both sharing and creating polyvalent meanings in relation to each other.

In some ways the stereotype created by Orientalism rears its head in these discussions, but by far, the influence of a dichotomy between "East" and "West" is far more prominent. By attributing the decline of cities to the indigenous character of the inhabitants, modern scholars seem to have embraced a negative attitude towards Near-easterners and a privileging of the Greek and Roman colonizers and their urban spaces. The privileging of orthogonal street plans is an example of "East" and "West" stereotypes. Most modern scholars have seen 
these city plans as examples of "Greek" cities in the east, characterizing nonorthogonal cities as "Islamic" or "Near Eastern" rather than Greek. However, when the Muslims founded their first cities, such as at Aqaba or Basra, they used the Orthogonal design. As Ball has pointed out, such design choices were available in the Near East even before the Greeks arrived.

Furthermore, Ball's argument that colonnaded streets are a Near Eastern, rather than "western" architectural style continues the binary debate of "East" vs. "West" even if he is arguing against the mainstream support of the "West." $\mathrm{He}$ is correct that the first colonnaded streets were in Antioch and not in Rome or Athens. In this case, we have a Near Eastern King (Herod of Judaea), beautifying a Greek-founded city then used by the Romans as their capital of the province of Syria with Greek-style columns in a new and innovative way. Binary understandings of this architectural form actually obscure the complexity of life in the Near East under the Romans.

In another sense, modern interest in the classical cities of the Near East implicitly gives validation to the act of colonization. If the Greco-Roman remains are the only ones of interest - the ones that represent the height of civilization, and the later, especially Muslim, cities represent a decline or debased form of an apex - one could argue that such thoughts serve to support current military activities in the Near East as well. After all, the Greco-Roman settlements could not have occurred without the military conquest of the Persian Empire by Alexander the Great. Though few archaeologists would like to admit it to themselves, the focus on the "Classical," Greco-Roman remains of the Near East privileges imperialism over the indigenous peoples of the Near East.

\section{The Early Islamic Conquests}

The second example that this paper uses is the early Islamic conquests of the seventh century CE, in which Roman control over the Near East and Egypt was lost forever and replaced with the rule of the successors of Muhammad, the Caliphs. The Islamic conquests impacted the eastern Roman Empire at a time of victory. In 630, the Emperor Heraclius and the Christian empire were celebrating the returning of the "True Cross" to Jerusalem after winning a twenty year conflict with the Persians. After the Roman defeat at the battle of Yarmuk in Syria in 636, resistance to the Islamic invasion was doomed to failure, and there was little chance that Syria and Palestine could have been reconquered by the Roman authorities. Soon, the Roman line of defense retreated to the Tarsus Mountains, and Egypt also fell. The permanent loss of the Near Eastern and Egyptian provinces severely damaged the prestige and economy of the surviving Roman Empire and rapidly led to a profound transformation of the Byzantine state (Haldon 1990).

"Western" Christians throughout history have viewed the early Islamic conquests in a derogatory fashion. Said believed that the early Islamic conquests and subsequent military expansion produced a kind of terror in "Western" culture that had to be controlled via representation (Said 1978: 59-60). As 
Tolan has demonstrated in his book Saracens, Medieval Christians fashioned an image of the Muslims that represented a threat to Christian interests (Tolan 2002). While modern scholars have generally tried to avoid such value statements; other popular writers, such as the military historian Ralph Peters, continue to produce Orientalist-like tracts. The title of Peters' book, Endless War: Middle Eastern Islam vs. Western Civilization, bares its thesis openly.

One avenue for approaching the underlying assumptions about the early Islamic conquests is the search for motivation. Christians, even today, typically wonder how or why Islam motivated the invasion of the Near East - as if Islam was the prime or only cause of the invasion, whereas few seek justification for Alexander the Great's conquest of the Near East. Such double standards reveal the implicit bias towards so-called "Western" civilization.

Surprisingly, non-orthodox Christians and the Jewish population of the Near East initially praised the Muslim conquerors as being more tolerant than the contemporary Christian Byzantine Empire (Lamoreaux 1996: 11-14). Whereas Christians in Europe generally confronted polytheists and sought to eradicate those faiths, Muslims (before the year 1000) generally encountered fellow monotheists (or those whose religions had monotheistic characteristics like the followers of Zoastrianism), who, although were believed to have an imperfect faith, could be seen as potential converts through persuasion, not violence (Bulliet 2004: 22-23). Arabic and Syriac texts mention Abu Bakr's instructions to the invading Arab armies which guaranteed the right of monks to worship freely, the safety of women, children, and the elderly, and protected the economic prosperity of the conquered areas. Thus those who willingly submitted to paying tribute were allowed to live without harassment, while those who refused were to be attacked (Tabari 1.1850, Palmer et al. 1993: 145, Hoyland 1997: 219-222). When the Muslims had to withdraw from Damascus before the Battle of Yarmuk, they even returned the jizya (tax on non-Muslims) because they could not defend the city! (Hill 1971: 74, no. 185)

Much scholarly work, including my book Mirage of the Saracen, has gone into understanding how early Christians reacted to the early Islamic conquests (Ward 2014). I found that Christian monks in the Sinai Peninsula pioneered the use of the word "Saracen" to describe the Muslims, a word that was previously applied to nomadic groups and contained the image that Muslims were evil child murderers. This image had little to do with actual Islamic belief or practices, but allowed the monastic communities of the Sinai and Near East to cast themselves into the role of the oppressed who sought the path of martyrdom. In choosing such a loaded term, the early Christians created the oppositional dichotomy reflected in Orientalism and the Clash of Civilizations thesis.

\section{Conclusion}

As Vasunia (2003) remarked about fifteen years ago, "scholars seem to be unable or uninterested in exploring the collusion between Classics and empire, despite the indisputable evidence for such collusion". We need to understand 
how our frames of reference impact our scholarship on pre-modern world society, especially in an era in which there are several groups, Christian and Muslim, who want to enlarge the cracks between Western civilization and Islam. For example, the Salafis want to return to the "good-old days" of the seventh century, even though the world as they envision it never existed. In order for us to prosper as scholars, we need to examine the lenses through which we engage in scholarship, especially in the Middle East. As I have argued in this paper, which is just a small contribution to scholarship, some scholars' unexamined biases towards Islamic culture, history, and society have in fact impacted their interpretation of urbanism in the Near East and their understanding of the Islamic conquests. I hope that this paper helps to initiate a discussion about our assumptions and the impact those biases may have on our work. The Orientalists that Said examines never had such a discussion, for they had internalized the belief that European society was unimpeachably superior. In doing so, they helped to create the conditions which justified European expansion into the Middle East. It is incumbent on us to not repeat that mistake.

\section{Acknowledgments}

Thanks to the University of Alabama at Birmingham Department of History for its generous support for research and travel. Some of the ideas in this paper were inspired by a former student, Grace Benton, who read and debated Said with me during a directed reading course at the University of Alabama at Birmingham.

\section{References}

al-Tabari (1993) The history of al-Tabari, vol. 11: The challenge to the Empires. Trans. by K. Blakinship. Albany: State University of New York Press.

Andrade N (2013) Syrian identity in the Greco-Roman world. Cambridge: Cambridge University Press.

Ball W (2000) Rome in the East: the transformation of an empire. London: Routledge.

Bilgrami A (2003) The clash within civilizations. Daedalus 132(3): 88-93.

Bottici C, Challand B (2010) The myth of the clash of civilizations. Abingdon, Oxon [England]: Routledge.

Butcher K (2003) Roman Syria and the Near East. Los Angeles: The J. Paul Getty Museum.

Bulliet R (2004) The case for Islamo-Christian civilization. New York: Columbia University Press.

Chiozza G (2002) Is There a Clash of Civilizations? Evidence from Patterns of International Conflict Involvement, 1946-97. Journal of Peace Research 39(6): 711-734. 
Fletcher R (2004) The cross and the crescent: Christianity and Islam from Muhammad to the Reformation. New York: Viking.

Fox J (2002) Ethnic minorities and the clash of civilizations: a quantitative analysis of Huntington's thesis. British Journal of Political Science 32(3): 415-434.

Freely J (2011) Light from the east: how the science of medieval Islam helped to shape the western world. London: I.B. Tauris.

Gregory D (2004) The colonial present: Afghanistan, Palestine, and Iraq. Malden, MA: Blackwell Pub.

Haldon J (1990) Byzantium in the Seventh Century: the transformation of a culture. Cambridge, Cambridge University Press.

Henderson E, Tucker R (2001) Clear and Present Strangers: The Clash of Civilizations and International Conflict. International Studies Quarterly 45(2): 317-338.

Hentsch T (1992) Imagining the Middle East. Montréal: Black Rose Books.

Hoyland RG (1997) Seeing Islam as others saw it: a survey and evaluation of Christian, Jewish, and Zoroastrian writings on early Islam. Princeton, N.J.: Darwin Press.

Hill D (1971) The Termination of Hostilities in the Early Arab Conquests, AD 634-656. London: Luzac.

Huntington S (1993) The clash of Civilizations? Foreign Affairs 72(3): 22-49.

Lewis B (1990) The Roots of Muslim Rage. The Atlantic (Sept 1990): 47-60.

Keegan J (2001) In this war of civilisations, the West will prevail. The Telegraph. Retrieved from http://bit.ly/2iLADoS.

Kennedy H (1985) "From Polis to Madina: Urban Change in Late Antique and Early Islamic Syria." Past and Present 106: 3-27.

Lamoreaux J (1996) Early eastern Christian responses to Islam. In J Tolan (ed) Medieval Christian Perceptions of Islam: A book of essays, 3-32. New York: Garland.

Lewis M, Wigen K (1997) The myth of continents: a critque of metageography. Berkley: University of California Press.

Lockman Z (2004) Contending visions of the Middle East: the history and politics of Orientalism. Cambridge: Cambridge University Press.

Lyons J (2009) The house of wisdom: how the Arabs transformed Western civilization. New York: Bloomsbury Press.

Menocal M (1987) The Arabic role in medieval literary history: a forgotten heritage. Philadelphia: University of Pennsylvania Press.

Millar F (1993) The Roman Near East 31 BC-AD 337. Cambridge, Mass.: Harvard University Press.

Neumayer E, Plümper T (2009) International Terrorism and the Clash of Civilizations. British Journal of Political Science 39(4): 711-734.

Palmer A, Brock S, Hoyland R (1993) The seventh century in the West-Syrian chronicles. Liverpool: Liverpool University Press.

Peters R (2010) Endless war: Middle-Eastern Islam vs. Western Civilization. Mechanicsburg, PA: Stackpole Books. 
Pirenne H (2001) Mohammed and Charlemagne. Mineola, N.Y.: Dover Publications.

Said E (1979) Orientalism. New York: Vintage Books.

Sartre M (2005) The Middle East Under Rome, Trans. by E. Rawlings. Cambridge, Mass.:Belknap Press of Harvard University Press.

Tolan J (2002) Saracens: Islam in the medieval European imagination. New York: Columbia University Press.

Vasunia P (2003) Hellenism and Empire: reading Edward Said. Parallax 9(4): 88-97.

Ward W (2014) Mirage of the Saracen: Christians and Nomads in the Sinai Peninsula in Late Antiquity. Oakland, CA: University of California Press. 
